\title{
GCKR Gene
}

National Cancer Institute

\section{Source}

National Cancer Institute. GCKR Gene. NCI Thesaurus. Code C116609.

This gene plays a role in the inhibition of carbohydrate phosphorylation. 